\title{
Crystal-associated cholangiopathy in sheep grazing Brachiaria decumbens containing the saponin protodioscin ${ }^{1}$
}

\author{
Karine B. Brum²*, Mitsue Haraguchi ${ }^{3}$, Ricardo A.A. Lemos ${ }^{4}$, Franklin Riet-Correa ${ }^{5}$ \\ and Maria Clorinda S. Fioravanti ${ }^{6}$
}

\begin{abstract}
Brum K.B., Haraguchi M., Lemos R.A.A, Riet-Correa F. \& Fioravanti M.C.S. 2007. Crystal-associated cholangiopathy in sheep grazing Brachiaria decumbens containing the saponin protodioscin. Pesquisa Veterinária Brasileira 27(1):39-42. Departamento de Patologia, Universidade Federal de Mato Grosso do Sul, Caixa Postal 549, Campo Grande, MS 79070-900, Brazil. E-mail: kbbrum@gmail.com

An outbreak of hepatogenous photosensitization is reported in a flock of 28 sheep grazing Brachiaria decumbens in Mato Grosso do Sul State, Central-Western Brazil. Seven lambs and an adult sheep were affected and 6 of them died. Two surviving affected lambs and one lamb without clinical signs had increased serum values of gamma glutamyltransferase, bilirubin, and cholesterol. In two adult unaffected sheep those parameters were within normal values. An adult sheep submitted to necropsy presented moderate body condition, unilateral corneal opacity, drying of the muzzle, moderate jaundice, increased lobular pattern of the liver, and a distended gallbladder. Histological lesions were epithelial degeneration, necrosis, and hyperplasia of small bile ducts. Mild amounts of foamy macrophages were observed, mainly in the centroacinar zone. Diffuse swelling and vacuolation were observed in hepatocytes. Crystal negative images were found within bile ducts, foamy macrophages, and the lumen of some renal tubules. The heart showed multifocal areas of degeneration and necrosis of the muscle fibers. Pasture samples (Brachiaria decumbens) contained $2.36 \%$ of protodioscin. No Pithomyces chartarum spores were found in the pasture. Samples from a similar neighboring $B$. decumbens pasture grazed by cattle without photosensitization contained $1.63 \%$ of protodioscin isomers. Outbreaks of photosensitization caused by Brachiaria spp. are common in cattle in the Brazilian Cerrado (savanna) with about 51 million hectares of Brachiaria spp pastures. Sheep farming has been recently developed in this region, and the number of sheep is increasing significantly. Because sheep are more susceptible than cattle to lithogenic saponins, poisoning by Brachiaria should be an important limiting factor for the sheep industry.
\end{abstract}

INDEX TERMS: Sheep, photosensitization, Brachiaria decumbens, protodioscin, steroidal saponin, cholangiopathy.

\footnotetext{
1 Received on August 24, 2006.

Accepted for publication on October 2, 2006.

2 Departamento de Patologia, Universidade Federal de Mato Grosso do Sul, Caixa Postal 549, Campo Grande, MS 79070-900, Brazil. *Corresponding author: kbbrum@gmail.com

3 Instituto Biológico, Av. Conselheiro Rodrigues Alves 1252, São Paulo, SP 04014-002, Brazil.

${ }^{4}$ Núcleo de Ciências Veterinárias, Universidade Federal de Mato Grosso do Sul, Av. Senador Felinto Müller 2443, Jardim Ipiranga, Caixa Postal 549, Campo Grande, MS 79070-900, Brazil.

${ }^{5}$ Hospital Veterinário, Universidade Federal de Campina Grande, Campus de Patos, Jatobá, PB 58700-000, Brazil.

${ }^{6}$ Escola de Veterinária, Universidade Federal de Goiás, Caixa Postal 131, Goiânia, GO 74001-970, Brazil.
}

RESUMO.- [Colangiopatia associada a cristais em ovinos alimentados com Brachiaria decumbens que contém a saponina protodioscina.] Um surto de fotossensibilização hepatógena é descrito em um rebanho de 28 ovinos mantidos em pastagem de Brachiaria decumbens no Estado de Mato Grosso do Sul, região Centro-Oeste do Brasil. Sete cordeiros e uma ovelha adulta foram afetados e seis deles morreram. Dois cordeiros com sinais clínicos e um cordeiro, aparentemente sem sinais clínicos, apresentaram elevação na atividade sérica de gama glutamiltransferase, e nos valores de bilirrubina e colesterol. Em dois animais adultos que não apresentavam sinais clínicos, esses parâmetros estavam dentro dos valores normais. Uma ovelha adulta submetida à necropsia apresentou moderada condição corporal, opacidade de córnea unilateral, focinho ressecado, 
moderada icterícia, padrão lobular hepático evidente e vesícula biliar acentuadamente distendida e repleta. As lesões histológicas consistiram de degeneração epitelial, necrose e hiperplasia de ductos biliares. Havia discreta quantidade de macrófagos espumosos, principalmente na região centroacinar, e tumefação e vacuolização difusas dos hepatócitos. Foram observadas imagens negativas de cristais dentro dos ductos biliares, macrófagos espumosos e lúmen de alguns túbulos renais. $O$ coração apresentou áreas multifocais de degeneração e necrose de fibras musculares. Amostras da pastagem (B. decumbens) apresentaram $2,36 \%$ de protodioscina e nenhum esporo de Pithomyces chartarum foi encontrado na pastagem. Amostras de uma pastagem vizinha semelhante (B. decumbens), que havia sido pastejada por bovinos que não desenvolveram fotossensibilização, apresentaram 1,63\% de protodioscina. Surtos de fotossensibilização causados por espécies de Brachiaria são comuns em bovinos no Cerrado brasileiro onde há aproximadamente 51 milhões de hectares plantados com essa gramínea. A criação de ovinos nesta região ganhou recente impulso e o número de ovinos vem aumentando significativamente. Como os ovinos são mais suscetíveis que os bovinos à intoxicação pelas saponinas litogênicas presentes nas espécies de Brachiaria spp, isso deve se constituir um fator importante para a criação de ovinos nessa região.

TERMOS DE INDEXAÇÃO: Ovinos, fotossensibilização, Brachiaria decumbens, protodioscina, saponina esteroidal, colangiopatia.

\section{INTRODUCTION}

Brachiaria species are important forages from tropical regions such as Africa, Asia, Australia and South America. In the Brazilian Cerrado (savanna) there are around 51 millions hectares of Brachiaria spp, mainly Brachiaria brizantha (30 millions ha), Brachiaria decumbens (15 millions ha), Brachiaria humidicola and others (6 millions ha) (Macedo 2005).

In Brazil, spontaneous cases of hepatogenous photosensitization by $B$. decumbens had been reported in cattle (Meagher et al. 1996, Lemos et al. 1997), sheep (Lemos et al. 1996a), and goats (Lemos et al. 1998). Poisoning by Brachiaria brizantha is reported in cattle (Lemos et al. 1996b) and in sheep (A.A. Lemos, personal communication). Initially, the disease was attributed to sporidesmin produces by Phitomyces chartarum spores in the pastures (Nobre \& Andrade 1976, Fioravanti 1999), however histologic alterations of cholangiohepatopathy associated to crystals similar to those found in poisoning by Panicum spp. (Bridges et al. 1987), Narthecium ossifragum (Ceh \& Hauge 1981), Agave lecheguilla (Camp et al. 1988) and Tribulus terrestris (Glastonbury et al. 1984) suggested that Brachiaria spp poisoning was due to lithogenic saponins contained in the plant (Lemos et al. 1996a, Lemos et al. 1997, 1998). Two steroidal sapogenins, yamogenin and diosgenin, were identified as the toxic principles of B. decumbens (Smith \& Miles 1993, Cruz et al. 2000), and the disease was reproduced in sheep through administration of fractionated extracts of $B$. decumbens (Cruz et al. 2001).

The aim of this study was to describe an outbreak of hepatogenous photosensitization in sheep grazing $B$. decumbens and to establish whether, in this case, the photosensitization was caused by higher levels of protodioscin, a steroidal saponin isolated from B. decumbens (Haraguchi et al. 2003), or by spores of $P$. chartarum present in the grass.

\section{MATERIALS AND METHODS}

An outbreak of hepatogenous photosensitization occurred at the end of November 2003 in a flock of 28 sheep (15 ewes, 9 lambs and 4 sheep of unknown age) of Santa Inês breed in a farm located in the municipality of Campo Grande, Mato Grosso do Sul, Brazil ( $20^{\circ} 22^{\prime} \mathrm{S}$ latitude and $54^{\circ} 45^{\prime} \mathrm{W}$ longitude). The flock coming from Northeastern Brazil had been introduced into the farm 50 days before the occurrence of the outbreak. The epidemiology of the outbreak and clinical signs of the affected sheep were registered during a visit of the farm, 22 days after the observation of the first case.

Blood samples for biochemical analysis were taken from 5 sheep of the flock. Three samples were from young animals, two affected lambs (Sheep 1 and 2) and one apparently healthy lamb (Sheep 3), and the two other samples were from apparently healthy ewes (Sheep 4 and 5). Serum samples were assayed for gamma glutamyltransferase (GGT), aspartate aminotransferase (AST), conjugated (CB), unconjugated (UCB) and total (TB) bilirubin, cholesterol (Chol), total protein (TP) and albumin (Alb). Enzymatic activities were determined or had their values corrected at $37^{\circ} \mathrm{C}$, and standardized commercial reagents were used (Labtest Diagnóstica S.A., Lagoa Santa, Minas Gerais State, Brazil).

One adult sheep was necropsied. For histological examination, selected tissues were fixed in $10 \%$ neutral buffered formalin, processed routinely for inclusion in paraffin, cut at $5 \mathrm{~mm}$ and stained with haematoxylin and eosin (HE) to be examined by light microscopy.

At the time of the visit of the farm, a sample of leaves from the Brachiaria decumbens pasture grazed by the sheep and from a neighboring similar pasture (B. decumbens) grazed by cattle without clinical signs of photosensitization were cut close to the soil on 20 sites of the paddock to determine the protodioscin levels, a saponin of $B$. decumbens. The samples were dried, ground and extracted with $96 \%$ ethanol. The concentrated ethanolic extract was dissolved in water and partitioned with butanol saturated with water. The butanolsoluble residue containing saponin, in according to Haraguchi et al. (2003), was submitted to semiquantitative analysis by the spectrophotometer method using Ehrlich reagent (Gjulemetowa et al. 1982) and compared with protodioscin standard, previously isolated from $B$. decumbens (Haraguchi et al. 2003).

The number of Phithomyces chartarum spores in the pastures was determined by the method described by Di Menna \& Bailey (1973).

\section{RESULTS}

All sheep grazed on a pasture of Brachiaria decumbens cv. Basilisk of about 1 hectare. The pasture was green and at the blooming phase. The flock was supplemented with a protein-energy-mineral mixture. In a neighboring pasture of 1.5 hectares grazed by 124 adult cattle without photosensitization $B$. decumbens had greater quantities of dry leaves. It was part of a pasture rotation system in which the animals stayed for 8 days.

Six lambs and an adult sheep showed clinical signs characterized by anorexia, depression, dry muzzle, dermatitis of the ears and face, and ocular and nasal yellowish secretion. Five lambs and an adult sheep died after a clinical manifestation period of up to 5 days. The three lambs examined (Sheep 1, 2 and 3) had increased values of GGT, CB, UCB, TB and cholesterol, but in the two adult healthy sheep these parameters were within normal range (Table 1$)$. 
Table 1. Gamma glutamyltransferase (GGT), aspartate aminotransferase (AST), conjugated bilirubin (CB), unconjugated bilirubin (UCB) and total bilirubin (TB), cholesterol (Chol), total proteins (TP) and albumin (Alb) serum content in sheep naturally poisoned with Brachiaria decumbens

\begin{tabular}{lcccccc}
\hline \multicolumn{1}{c}{ Test } & \multicolumn{5}{c}{ Sheep $^{\mathrm{a}}$} & $\begin{array}{c}\text { Reference } \\
\text { values }^{\mathrm{b}}\end{array}$ \\
\cline { 2 - 6 } & 1 & 2 & 3 & 4 & 5 & $20-52$ \\
GGT (U/l) & 271 & 224 & 218 & 48 & 58 & $20-50$ \\
AST (U/l) & 148 & 300 & 240 & 42 & 50 & $60-280$ \\
CB (mg/dl) & 2.26 & 1.75 & 1.0 & 0.15 & 0.1 & $0-0.27$ \\
UCB (mg/dl) & 4.07 & 1.44 & 2.18 & 0.365 & 0.37 & $0-0.12$ \\
TB (mg/dl) & 6.33 & 3.19 & 2.2 & 0.515 & 0.4 & $0.1-0.5$ \\
TP (g/dl) & 7.1 & 6.8 & 7.5 & 7.2 & 7.5 & $6-7.9$ \\
Alb (g/dl) & 2.5 & 2.7 & 2.4 & 2.8 & 2.7 & $2.4-3.0$ \\
Chol (mg/dl) & 100 & 134 & 103 & 49 & 53 & $52-76$
\end{tabular}

a Sheep 1 and 2 were affected lambs, Sheep 3 was an apparently unaffected lamb, and Sheep 4 and 5 were apparently healthy ewes.

b Kaneko et al. 1997.

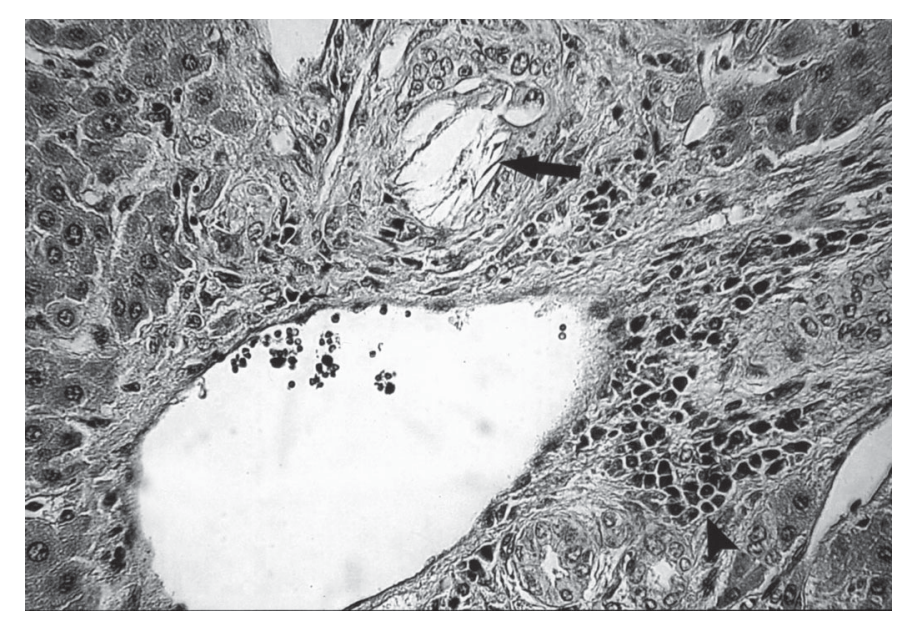

Fig.1. Negative images of crystals in bile ducts (arrow), and periductal infiltrated inflammatory mononuclear cells (arrowhead) in the liver of an adult sheep. HE, obj.40.

At necropsy, an adult sheep in moderate body condition showed unilateral corneal opacity, dry muzzle, moderate jaundice, increased lobular pattern of the liver and a distended gallbladder.

Histologically, the main alteration in the liver were the cholesterol-like, needle-shaped, crystals negative images in the lumen of some bile ducts, associated with a periductular moderate infiltration of mononuclear inflammatory cells (Fig.1). In the small bile ducts epithelial cells were degenerated or necrotic. Proliferation of bile duct cells was also observed. There was a diffuse severe swelling and vacuolation of hepatocytes. A mild amount of foamy macrophages was observed, mainly in the centroacinar zone, some of them also containing negative images of crystals. The heart showed multifocal areas of degeneration and necrosis of muscular fibers associated with connective tissue proliferation and mild infiltration of mononuclear cells. In the kidneys, cholesterol-like, needle-shaped, negative images of crystals were observed in the lumen of some tubules, occasionally with presence of giant multinucleate cells.
No Pithomyces chartarum spores were found in the pasture samples from the sheep paddock, and only 5,000 spores per gram of pasture, were found in the paddock grazed by cattle. The levels of protodioscin of B. decumbens were 2.36 and $1.63 \%$ for the sheep and cattle paddocks, respectively.

\section{DISCUSSION}

The finding of a crystal-associated cholangiopathy in sheep grazing Brachiaria decumbens, and the absence of Pithomyces chartarum spores in the pasture indicated that the disease was caused by the ingestion of steroidal lithogenic saponins. The identification of great amounts of protodioscin, a furostanol steroid saponin, for the first time in a $B$. decumbens pasture causing photosensitization, suggests that this substance should be the main cause of the disease. In previous papers the substances identified in the pastures or in the rumen content of affected animals were diosgenin and yamogenin sapogenins, and their metabolites smilagenin, sarsasapogenin epislamigenin, and episarsapogenin (Meagher et al. 1996, Cruz et al. 2000). In the rumen the sapogenins, diosgenin and yamogenin, are metabolized to epismilagenin and episarsasapogenin, which are conjugated with glucuronic acid and then combine with salts of $\mathrm{Ca}^{2+}$ to form crystals in biliar ducts. Crystal formation probably involves the hydrolysis of the sugars from the saponin followed by reduction of the 5-6 double bond, epimerization of the 3-b$\mathrm{OH}$ to $3-\mathrm{a}-\mathrm{OH}$ and finally conjugation with the glucuronic acid (Miles et al. 1991).

On the serum biochemistry, the rise on GGT, CB, UCB, and cholesterol in the affected and unaffected lambs indicate liver damage due to cholestasis. By the contrary, in two adult animals GGT, CB, UCB, and cholesterol were within normal levels. These results and the fact than only one adult sheep was affected confirm previous reports that young sheep are more susceptible to the poisoning than adult sheep (Button et al. 1987).

The gross and microscopic lesions observed were similar to those reported previously in animals grazing Brachiaria species (Graydon et al. 1991, Lemos et al. 1996a,b, Cruz et al. 2000, Driemeier et al. 2002). Foamy macrophages, mainly in the liver, but also in hepatic and mesenteric lymph nodes and gut are observed in affected and healthy animals grazing Brachiaria spp. (Driemeier et al. 1998, 1999, Fioravanti 1999, Riet-Correa et al. 2002). Histologically and ultrastructurally these cells present negative crystals images (Driemeier et al. 1998) suggesting that they are formed in consequence of the crystal phagocytosis. These foamy macrophages have not been reported in poisoning by other plants containing lithogenic saponins, except for the report of hypertrophic Kupffer cells containing crystals observed in Panicum coloratum poisoning (Bridges et al. 1987).

Outbreaks of photosensitization caused by Brachiaria spp. are common in cattle in the Brazilian Cerrado (savanna) where there are about 51 million hectares of Brachiaria spp pastures. Sheep farming has been recently developed in this region, and the number of sheep is increasing significantly. Because sheep are more susceptible than cattle to lithogenic saponins, poisoning by Brachiaria should be an important limiting factor for sheep industry. 


\section{CONCLUSION}

The high levels of protodioscin saponin in Brachiaria decumbens grazed by sheep with crystal-associated cholangiopathy indicate that this furostanol steroid saponin is the main responsible for photosensitization caused by this grass species.

Acknowledgements.- To the "Coordenação de Aperfeiçoamento de Pessoal de Nível Superior" (CAPES) for financial support, and to the veterinarian Luciano G. de Oliveira for his contribution to the accomplishment of this paper. This study was financially supported by the "Programa de Apoio a Núcleos de Excelência” (PRONEX), Grant no.7697102600.

\section{REFERENCES}

Bridges C.H., Camp B.J., Livingston C.W. \& Bailey E.M. 1987. Kleigrass (Panicum coloratum L.) poisoning in sheep. Vet. Pathol. 24:525-531.

Button C., Paynter D.I., Shiel M.J., Corlson A.R., Paterson P.J. \& Lyford R.L. 1987. Crystal-associated cholangiohepatopathy and photosensitization in lambs. Austr. Vet. J. 64 (6):176-180.

Camp B.J., Bridges C.H., Hill D.W., Patamalai B. \& Wilson S. 1988. Isolation of steroidal sapogenin from the bile of a sheep fed Agave lecheguilla. Vet. Hum. Toxicol. 30:533-535.

Ceh L. \& Hauge J.G. 1981. Alveld-producing saponins. I. Chemical studies. Acta Vet. Scand. 22:391-402.

Cruz C., Driemeier D., Pires V.S., Colodel E.M., Taketa A.T.C. \& Schenkel E.P. 2000. Isolation of steroidal sapogenins implicated in experimentally induced cholangiopathy of sheep grazing Brachiaria decumbens in Brazil. Vet. Hum. Toxicol. 42:142-145.

Cruz C., Driemeier D., Pires V.S. \& Schenkel E.P. 2001. Experimentally induced cholangiopathy by dosing sheep with fractionated extracts from Brachiaria decumbens. Vet. Diag. Invest. 13:170-172.

Di Menna M.E. \& Bailey J.R. 1973. Pithomyces chartarum spore counts in pasture. N.Z.J. Agric.Res. 16:343-351.

Driemeier D., Barros S.S., Peixoto P.V., Tokarnia C.H., Döbereiner J. \& Brito M.F. 1998. Estudo histológico, histoquímico e ultra-estrutural de fígados e linfonodos de bovinos com presença de macrófagos espumosos ("foam cells"). Pesq. Vet. Bras. 18:29-34.

Driemeier D., Döbereiner J., Peixoto P.V. \& Brito M.F. 1999. Relação entre macrófagos espumosos ("foam cells") no fígado de bovinos e ingestão de Brachiaria spp no Brasil. Pesq. Vet. Bras. 19:79-83.

Driemeier D., Colodel E.M., Seitz A.L., Barros S.S. \& Cruz C.E.F. 2002. Study of experimentally induced lesions in sheep by grazing Brachiaria decumbens. Toxicon 40:1027-1031.

Fioravanti M.C.S. 1999. Incidência, avaliações clínica, laboratorial e anatomopatológica da intoxicação subclínica por esporidesmina em bovinos. Tese de Doutorado em Medicina Veterinária, Faculdade de Medicina Veterinária e Zootecnia, Universidade Estadual Paulista, Botucatu, SP, Brasil. 257p.

Gjulemetowa R., Tomowa M., Simowa M., Pangarowa T. \& Peewa S. 1982. Über die Bestimmung von Furostanolsaponinen im Präparat Tribestan. Pharmazie 37:296.

Glastonbury J.R.W., Doughty F.R., Whitaker S.J. \& Sergeant E. 1984. A syndrome of hepatogenous photosensitization, resembling geldikkop, in sheep grazing Tribulus terrestris. Aust. Vet. J. 61:314-316.

Graydon R.J., Hamid H., Zaha R.I.P. \& Gardiner C. 1991. Photosensitization and crystal-associated cholangiohepatopathy in sheep grazing Brachiaria decumbens. Aust. Vet. J. 68:234-236.

Haraguchi M., Cunha H.A., Mimaki Y., Brum K.B., Lemos R.A.A., Yokosuka A. \& Sashida Y. 2003. Furostanol glicosídicos nas folhas de Brachiaria decumbens. 26 $6^{\mathrm{a}}$ Reun. Anu. Soc. Bras. Química, Poços de Caldas, MG. PN066.

Lemos R.A.A., Ferreira L.C.L., Silva S.M., Nakazato L. \& Salvador S.C. 1996a. Fotossensibilização e colangiopatia associada a cristais em ovinos em pastagem com Brachiaria decumbens. Ciência Rural, Santa Maria, 26:109113.

Lemos R.A.A., Osório A.L.A.R., Rangel J.M.R. \& Herrero Jr G.O. 1996b. Fotossensibilização e colangiopatia associada a cristais em bezerros ingerindo Brachiaria brizantha. Arqs Inst. Biol., São Paulo, 63(Supl):22.

Lemos R.A.A., Salvador S.C. \& Nakazato L. 1997. Photosensitization and crystal associated cholangiohepatopathy in cattle grazing Brachiaria decumbens in Brazil. Vet. Hum. Toxicol. 39:376-377.

Lemos R.A.A., Nakazato L., Herrero Jr G.O., Silveira A.C. \& Porfírio L.C. 1998. Fotossensibilização e colangiopatia associada a cristais em caprinos mantidos sob pastagens de Brachiaria decumbens no Mato Grosso do Sul. Ciência Rural, Santa Maria, 28:507-510.

Macedo M.C.M. 2005. Pastagens no Ecossitema Cerrados: evolução das pesquisas para o desenvolvimento sustentável. Anais 42 ${ }^{a}$ Reun. Anu. Soc. Bras. Zootecnia, Goiânia, p.56-84.

Meagher L.P., Miles C.O. \& Fagliari J.J. 1996. Hepatogenous photosensitization of ruminants by Brachiaria decumbens and Panicum dichotomiflorum in the absence of sporidesmin: lithogenic saponins may be responsible. Vet. Hum. Toxicol. 38:271-274.

Nobre D. \& Andrade S.O. 1976. Relação entre fotossensibilização em bovinos jovens e a gramínea Brachiaria decumbens Stapf. Biológico, São Paulo, 42:249-258.

Riet-Correa G., Riet-Correa F., Schild A.L. \& Driemeier D. 2002. Wasting and death in cattle associated with chronic grazing of Brachiaria decumbens. Vet. Hum. Toxicol. 44(3):179-180.

Smith B.L. \& Miles C.O. 1993. A role for Brachiaria decumbens in hepatogenous photosensitization of ruminants. Vet. Hum. Toxicol. 35:256-257. 